\title{
REVIEW TANAMAN SEMBUNG [Blumea balsamifera (L.)]
}

\author{
Setyo Sri Rahardjo \\ Bagian Farmakologi Fakultas Kedokteran Universitas Sebelas Maret Surakarta \\ Dewan Pembina POKJANAS TOI
}

\begin{abstract}
ABSTRAK
Sembung [Blumea balsamifera (L.)] merupakan spesies tanaman yang masuk dalam genus Blumea, family Astereceae (Compositae). Dibeberapa daerah di Indonesia dikenal dengan berbagai nama yang berbeda, demikian pula di beberapa negara mempunyai nama yang berbeda.

Tanaman berupa perdu, batang hijau tua tegak bulat, daun tunggal berbentuk lonjong, bagian pangkal dan ujung lancip, pinggrir bergerigi, pertulangan daun menyirip. Bunga majemuk, bertangkai dengan mahkota bunga berwarna putih kekuningan. buah berwana putih kecoklatan bentuk kotak silindris, biji berbentuk pipih dan berwarna putih, akar tunggang berwarna putih susu.

Di Indonesia Blumea balsamifera relatif belum banyak dibudidayakan, namun budidaya tanaman sembung relatif mudah. Bagian tanaman yang sering digunakan adalah daun dan batang. Hasil identifikasi kandungan fitokimia menunjukkan lebih dari 100 bahan kimia seperti minyak atsiri, flavonoid, alkohol, dihidroflavon, sterol, asam organik, monoterpen, sesquiterpen, triterpen.

Bagian tanaman Blumea balsamifera yang paling sering digunakan untuk pengobatan adalah daun. Secara tradisional di Indonesia sembung digunakan untuk pengobatan rematik, nyeri haid, influenza, kembung, sakit tulang, diare, sariawan, asma, angina pectoris. Tanaman sembung juga mempunyai potensi sebagai antcancer, hepatoprotektor, antitirosin, antidiabetik, antiobesitas, antiaterogenik, penyembuhan luka, antioksidan, antiperdarahan, antiarthritis, antiinflamasi, antibakteri, antiplasmodial, dan beberapa potensi lain masih perlu banyak diteliti.
\end{abstract}

Keyword: Blumea balsamifera (L.), review

\section{BOTANI DAN EKOLOGI}

\section{Botani}

Sistematika tanaman sembung adalah sebagai berikut:

Kingdom : Plantae

Subkingdom : : Embryophyta

Division : Spermatophyta

Subdivision : : Angiospermae

Class : Dicotyledonae

Order : Asterales

Family : : Astereceae (Compositae)

Genus : Blumea

Species $\quad$ : Blumea balsamifera (L.) DC. (BPOM RI, 2008) 


\section{Sinonim}

Conyza balsamifera L. (Rain et al, 2007); Baccharis salvia Lour., Pluchea balsamefera (Linn.) Less (Sudiarto dan Putera, 2008); Conyza appendiculata Blume (Aguilar, 1999).

\section{Nama Daerah}

Sumatera: sembung (Melayu); Jawa:,sembung utan (Sunda), kemandin (Madura), sembung, sembung gontung, sembung mingsa, sembung gula, sembung kuwuk, sembung lelet, sembung legi (Jawa) (BPOM RI, 2008); Ternate: mandikapu; Bali: sembung; (Hariana, 2014)

\section{Nama Asing}

Inggris: Ngai champora; China: ai na xiang (Hariana, 2014); Malaysia: sembong, sembuh, sembing, telinga kerbau, capu, sapu (Rain et al, 2007); Perancis: camphier; Kamboja: bai mat; Myanmar: poung-ma-theing; Thailand: kamphong, nat-yai; Filipina: sambong, lakadbulan, subsub; Vietnam: c[aa]y d[aj] i bi, c[aa]y t [uwf] bi(Aguilar, 1999).

\section{Pertelaan}

Tanaman berupa perdu dengan tinggi lebih dari $4 \mathrm{~m}$. Batang hijau tua tegak bulat dengan diameter 3-5 cm, bagian atas batang berbulu lebat dan aromatis. Daun tunggal berukuran panjang 6-30 $\mathrm{cm}$ dan lebar 1,5-12 $\mathrm{cm}$ berbentuk lonjong, bagian pangkal dan ujung lancip, pinggrir bergerigi, pertulangan daun menyirip dan terdapat 2-3 daun tambahan pada tangkai daunnya. Permukaan daun bagian atas agak kasar, sedangkan bagian bawah daun berambut rapat dan halus. Bunga majemuk, bertangkai dengan mahkota bunga berwarna putih kekuningan, terdapat di ketiak daun dan ujung batang, panjang bunga $0,9 \mathrm{~cm}$. Buah berwana putih kecoklatan dengan bentuk berupa kotak silindris berukuran panjang $1 \mathrm{~mm}$, keras dan berambut. Biji tanaman berbentuk pipih dan berwarna putih. Akar berupa akar tunggang dan berwarna putih susu (Kinho et al, 2011; BPOM RI, 2008; Sudiarto dan Putera, 2008).

\section{Keanekaragaman}

Genus Blumea terdiri dari 50 spesies. Blumea termasuk dalam suku Inuleae dan tampaknya terkait erat dengan genus Laggera dan Blumeopsis. Bahkan Blumea, Langgera dan Blumopsis telah diusulkan untuk menggabungkan tiga genus tersebut, tetapi studi terbaru menempatkan dua terakhir di suku Pluchea. Dahulu Blumea balsamifera sering disamakan dengan Pluchea balsamefera (Linn.) Less juga mungkin karena hal tersebut.Studi sitologi dari tanaman Blumea balsamifera menunjukkan bahwa tanaman ini memiliki jumlah kromosom somatik 2n=18 (Alonzo, 1999)

\section{Persebaran}

Sembung (Blumea balsamifera) berasal dari Asia tropis, dari India hingga Indo-China, China selatan, Taiwan hingga wilayah Malaysia, Indonesia dan Filipina. Di Indonesia sembung ditemukan di seluruh kepulauan (Aguilar, 1999).

Blumea balsamifera adalah tumbuhan yang selalu hijau dan berbunga di sepanjang tahun. Polinasi biasanya dilakukan oleh serangga. Sembung memiliki kecenderungan tumbuh liar di pinggir jalan dan tanah lapang, di tanah yang penuh dengan rumput atau semak belukar, di tepi sungai, hutan sekunder, dataran rendah dan wilayah pegunungan hingga ketinggian 2200 - $3000 \mathrm{~m}$ dpl. Umumnya sembung senang tumbuh di daerah yang lembab walaupun diantara batu-batu, namun ditemukan juga di daerah yang bermusim kering ringan sampai berat. Sembung toleran terhadap kebakaran dan mudah berkecambah kembali dari dalam 
tanah sehingga sering ditemukan di padang rumput sesudah terbakar atau bekas kebun. (Aguilar, 1999; Alonzo, 1999, Kinho et al, 2011).

\section{PERBANYAKAN DAN BUDIDAYA}

Di Indonesia Blumea balsamifera relatif belum banyak dibudidayakan. Namun, budidaya tanaman sembung relatif mudah. Adapun tahapan budidaya sembunga adalah sebahai berikut.

1. Pembibitan

Sembung(Blumea balsamifera) dikembangbiakkan dengan menggunakan benih biji atau siwalan (bassal cutting atau root cutting). Pemberian air dilakukan dengan teratur namun tidak terlalu banyak. Benih biji memiliki tingkat perkecambahan $95 \%$ dan menurun $10 \%$ ketika disimpan selama 12 bulan (Alonzo, 1999).

2. Pemilihan lokasi tanam

Lokasi yang baik adalah tanah yang agak lembab dan tidak terlalu kering serta sedikit terbuka. Sembung tidak terlalu tahan terhadap kekeringan. Bidang tanah dibuat dengan ukuran 0.5-10 m ×1-1.50 m (De Guzman, 2014).

3. Penanaman

Setelah 2 minggu, tanaman bisa dipindahkan untuk ditanam pada tempat yang mendapatkan cahaya matahari optimal. Penyiraman penting dilakukan untuk menjaga kelembaban lahan. Suhu optimum adalah $30^{\circ} \mathrm{C}$ (Alonzo, 1999).

4. Pemeliharaan

Pemeliharaan dalam budidaya sembung terdiri atas penyiangan, pemupukan, dan pengendalian hama. Secara umum sembung memerlukan penyiangan. Proses penyiangan yang baik adalah dengan menghilangkan tuntas gulma, bukan hanya memotong gulma. Di Filipina, sembung berespon baik dengan pemberian pupuk amonium sulfat $40 \mathrm{~g}$ dan solophos fosfat $100 \mathrm{~g}$ per tanaman. Hama yang sering menyerang Blumea balsamifera adalah Endophyllum blumea yang bisa mengakibatkan perontokan daun, Cercospora sp yang menyerang saat musim hujan dan mengakibatkan bercak orange pada daun, dan Gleosporium sp. yang sering mengakibatkan antraknosa (Alonzo, 1999).

5. Produktivitas

Di Vietnam, dapat dihasilkan daun sembung sebanyak 50 ton/ha, yang dapat menghasilkan 50-200 borneol (Alonzo, 1999).

\section{PANEN DAN PASCA PANEN}

\section{Bagian Tanaman yang Digunakan}

Daun dan batang

\section{Waktu panen}

Di China, Jiang et al (2014) melaporkan bahwahasil panen dan esktraksi sembung meningkat secara tajam bila dilakukan pada bulan Oktober sampai Desember. Sedangkan peneitian Isnawati et al (2006) tentang standarisasi simplisia dan ekstrak etanol daun 
sembung dari Malang, Tawangmangu, dan Bogor menjelaskan bahwa pemanenan Blumea balsimefera dilakukan pada bulan Juli sampai Agustus di musim kemarau.

\section{Cara Panen}

Panen bisa dilakukan dengan cara mengangkat seluruh bagian tanaman ataupun hanya daunnya saja. Pemanenan bisa dilakukan 4 kali selama satu tahun. Pemanenan daun lebih baik dilakukan jika daun sudah tua karena memiliki kandungan senyawa aktif optimal, jika terletak pada batang atau cabang yang menerima sinar matahari maksimal dan daun membuka penuh sehingga asimilasi terjadi sempurna (Alonzo, 1999).

\section{Pengelolaan Paskapanen}

Untuk konsumsi lingkup keluarga, daun yang sudah dipanen dibersihkan dengan air bersih lalu digunakan untuk obat baik direbus lalu diminum ataupun untuk obat luar. Sedangkan untuk kepentingan komersial, daun dikeringkan di bawah sinar matahari dan mendapat ventilasi yang cukup. Dengan distilasi bisa didapatkan 0,1-0,5\% minyak. Minyak atsiri Blemua balsamifera yang mengandung bornel dan camphor bisa diproses secara kimia lebih lanjut untuk produksi parfum (Alonzo, 1999).

\section{Penyimpanan}

Disimpan dalam wadah yang bersih, kedap air dan tertutup rapat, di tempat yang kering dan terlindung dari cahaya matahari.

\section{FITOKIMIA DAN STANDARDIDASI}

Hasil identifikasi kandungan fitokimia Blumea balsamifera menunjukkan lebih dari 100 bahan kimia seperti minyak atsiri, flavonoid, alkohol, dihidroflavon, sterol, asam organik, monoterpen, sesquiterpen, triterpen. Kebanyakan studi yang ada meneliti tentang flavonoid dan minyak atsiri yang memiliki efek bioaktivitas baik in vivo maupun in vitro (Pang et al, 2014).

Balangcod et al (2012) mengidentifikasi kandungan fitokimia Blumea balsamifera yaitu alkaloid, treroid, tanin, dan glikosida. Sedangkan Isnawati (2006) melaporkan hasil mengidentifikasi kandungan Blumea balamifera dari Malang, Tawangmangu, dan Bogor antara lain tanin, flavonoid, L-campor, borneol, caryophylene, $\beta$-camphene, dan $\alpha$ humulene.

\section{Minyak atsiri}

Minyak atsiri Blumea balsamifera berupa cairan kuning berminyak dengan aroma yang unik. Kebanyakan minyak atsiri Blumea balsamifera didapatkan di daun dan cabang (Bhuiyan, 2009, Jiang, 2014). Jiang (2014) meneliti terdapat 42 jenis kandungan yang ada dalam minyak atsiri Blumea balsamiferayang memiliki efek antitumor dan antioksidan. Kandungan tersebut antara lain caryophyllene (19.28\%); 1,7,7-trimethyl-(1S-endo)bicyclo[2.2.1] heptan-2-ol (15.54\%); caryophylleneoxide (11.20\%); thujopsene (10.36\%); 3-t-butyl-4-methoxyphenol methyl derivative (6.04\%); guaiol (5.03\%); 1,3,4,5,6,7hexahydro-2,5,5-trimethyl-2H-2,4 $\alpha$ - ethanonaphthalene (4.89\%); decahydro- $\alpha, \alpha, 4 \alpha-$

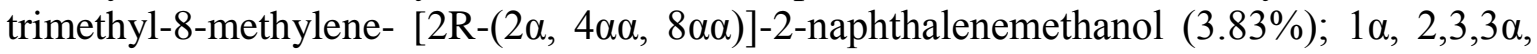

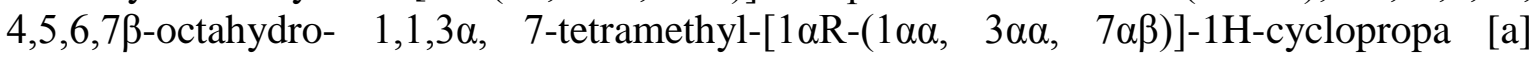
naphthalene (2.97\%); 4,4-dimethyl-tetracyclo[6.3.2.0(2,5).0(1,8)]tridecan-9-ol $(2.54 \%)$; 2 methoxy-3- (2-propenyl)-phenol (1.93); 1,1,4,8-tetramethyl- cis, cis, cis-4,7,10cycloundecatriene $(1.67 \%)$. 
Sedangkan Bhuiyan (2009) mengidentifikasi 50 kandungan minyak atsiri pada daun sembung, dengan kandungan paling tinggi adalah borneol, caryophylle, ledol, tetracyclo $[6,3,2,0,(2.5) .0(1,8)$ tridecan-9-ol, 4,4-dimethyl]. Kandungan minyak atsiri daun sembung secara lengkap disajikan seperti pada tabel1.

Tabel 1. Kandungan minyak atsiri daun sembung (Bhuiyan, 2009)

\begin{tabular}{|l|l|}
\hline \multicolumn{1}{|c|}{ Nama kandungan } & \multicolumn{1}{|c|}{} \\
\hline$\alpha$-pinene & 0,48 \\
\hline Camphene & 0,47 \\
\hline$\beta$-pinene & 1,16 \\
\hline 1-octen-3-ol & 0,71 \\
\hline$\beta$-myrcene & 0,06 \\
\hline 6-undecanol & 0,11 \\
\hline Limonene & 0,19 \\
\hline (E) ocimene & 1,16 \\
\hline Linalool & 1,31 \\
\hline Camphor & 0,11 \\
\hline Borneol & 33,22 \\
\hline Cuminal & 0,06 \\
\hline Perillaldehyde & 0.22 \\
\hline Neryl acetate & 0,40 \\
\hline Perillol & 0,09 \\
\hline Acetic acid & 2,08 \\
\hline Thujopsene-13 & 4,42 \\
\hline Aromadendrene, dehydro & 0,12 \\
\hline Guaina-3,9-diene & 0,75 \\
\hline §-selinene & 0,18 \\
\hline 3-Adamantanecarboxylic acid,phenylester & 0,28 \\
\hline Cyclobexene,1-(2-methyl-2-cyclopentenyl) & 0,10 \\
\hline Dimethoxydurene & 3,59 \\
\hline Caryophyllene & 8,24 \\
\hline$\alpha$-Caryophyllene & 1,19 \\
\hline Aromadendrene & 2,91 \\
\hline Patchoulene & 0,11 \\
\hline$\alpha$-Selinene & 0,32 \\
\hline$\gamma$-Muurolene & 0,31 \\
\hline$\delta$-Cadinene & 0,26 \\
\hline Epicedrol & 0,49 \\
\hline Neoclovene, dihydro & 0,10 \\
\hline$\beta$-Elemene & 1,23 \\
\hline Geranyl iso-valerate & 0,07 \\
\hline Ledol & 7,12 \\
\hline Germacrene-D-4-ol & 0,22 \\
\hline Caryophyllene oxide & 4,07 \\
\hline Guaiol & 0,61 \\
\hline Globulol & \\
\hline 2(1H)-naphthalene, octahydro-4-5amethyl-7-(1- \\
\hline
\end{tabular}




\begin{tabular}{|l|l|}
\hline methylethyl) & \\
\hline 1,1-Dimethyl adamantane & 0,86 \\
\hline$\gamma$-eudesmol & 3,18 \\
\hline $\begin{array}{l}\text { Tetracyclo [6,3,2,0,(2.5).0(1,8)tridecan-9-ol, } \\
\text { 4,4dimethyl] }\end{array}$ & 5,18 \\
\hline 4,4-Demethyladamanlaer-2-ol & 1,10 \\
\hline Cycloisolongifolene, 8,9-dehydro & 0,16 \\
\hline Carotol & 0,47 \\
\hline Aromadendrene oxide & 0,17 \\
\hline Adamantane, cyclopropyledene & 0,11 \\
\hline Isopatchoulane & 0,13 \\
\hline Phytol & 4,63 \\
\hline
\end{tabular}

\section{Flavonid}

Komponen flavonoid merupakan komponen non-volatile yang utama pada Blumea balsamifera. Huang et al (2006) menghitung flavonoid total yang ada pada beberapa bagian tumbuhan sembung dan didapatkan komponen flavonoid sembung terbanyak ada di daun $(2,94 \%)$, diikuti batang $(1,36 \%)$ dan cabang $(1,21 \%)$.

Beberapa kandungan flavonoid yang ada dalam sembung antara lain davidigenin; catechin; ayanin; blumeatin; ombuine; rhamnetin; velutin; persicogenin; luteolin; tamarixetin; dihydroquercetin-7,4'-dimethyl ether; luteolin-7-methyl ether; quercetin; 5,7,3',5'tetrahydroxyflavanone; dihydroquercetin-4'- methyl ether; ',4',5-trihydroxy-7methoxyflavanone; xanthoxylin; blumeatin; dihydroquercetin-7; 4'-dimethylethe; dan 5,4';dihydroxy-7-methoxyflavone; 3,3'-dimethyoxyquercetin; 3,7dimethylquercetin;quercetin-3,7,3-trimethylether; 3,7,4'-trimethylquercetin; 3',4',5trihydroxy-3,6,7-trimethoxyflavone (Pang et al, 2014; Ali et al, 2005, Fazilatun, 2003).

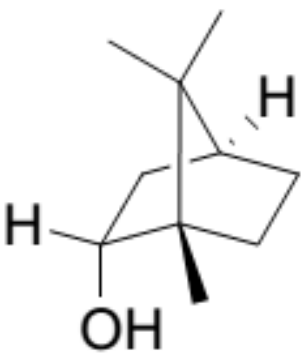

L-borneol

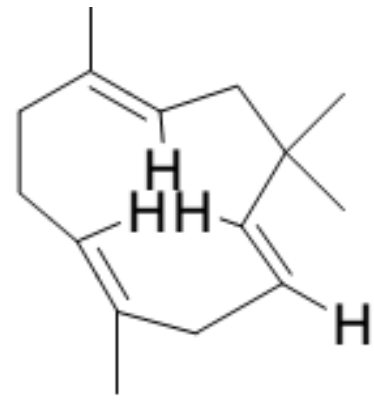

$\alpha$-caryophyllene

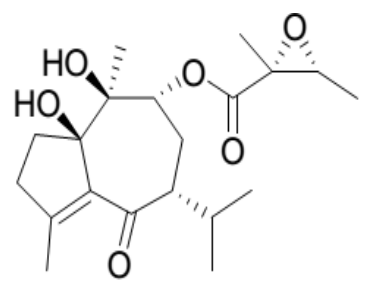

blumen A

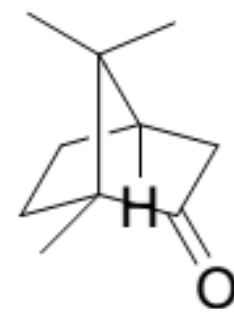

champor

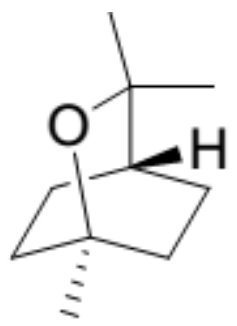

1,8 cineole

Gambar 1. Beberapa senyawa dalam Blumea balsamifera 


\section{Penggunaan}

\section{ETNOMEDISIN DAN FARMAKOLOGI}

Bagian tanaman Blumea balsamifera yang paling sering digunakan untuk pengobatan adalah daun. Secara tradisional di Indonesia sembung digunakan untuk pengobatan rematik, nyeri haid, influenza, kembung, sakit tulang, diare, sariawan, asma, angina pectoris (Dalimartha, 2005; Kinho, 2011), kolera, sakit perut, tidak nafsu makan, nyeri dada, penyakit jantung, demam, bronkhitis, epitaksis. Masyarakat biasa menggunakan daun sembung untuk obat dengan cara memotong daun kecil-kecil, rebus sampai tersisa sebagian, lalu meminumnya (Hariana, 2014). Namun untuk pengobatan wasir, luka memar, bisul, radang kulit, dan gatal-gatal, penggunaan daun sembung adalah sebagai obat luar (Dalimartha, 2005).

\section{Antikanker}

Efek antikanker sembung didapat karena kandungan dihidroflavonol, luteolin-7-methyl ether, dan bahwa blumealactone A, B, dan C. Tumor necrosis factor (TNF)- related apoptosis-inducing ligand (TRAIL) menginduksi apoptosis sel yang tidak normal namun tidak pada sel yang normal, sehingga berperan sebagai agen antikanker. Pada kasus leukemia/ limfoma, sel kanker adult T-cell leukemia/ lymphoma mengekspresikan TRAIL death receptor DR4 (TRAIL-R1) atau DR5 (TRAIL-R2) yang resisten terhadap TRAIL. Dihidroflafonol dapat meningkatkan aktivitas promotor TRAIL-R2 dan memacu ekspresi dari surface protein di p-53 independen sehingga dapat terjadi apoptosis yang terinduksi ligan (TRAIL) (Hasegawa, 2006). Selain itu kandungan luteolin-7-methyl ether memiliki efek sitotoksis yang kuat untuk melawan sel line kanker paru-paru manusia (NCI-H187) dengan nilai $\mathrm{IC}_{50} \quad 1,29 \mu \mathrm{g} / \mathrm{mL}$. Luteolin-7-methyl ether juga memiliki aktivitas sitotoksisitas moderat untuk melawan sel line kanker mulut (KB) dengan nilai IC50 17.83 $\mu \mathrm{g} / \mathrm{mL}$ (Saewan, 2011). Fujinomoto et al (1988) menyimpulkan bahwa blumealactone A, $\mathrm{B}$, dan $\mathrm{C}$ dari daun sembung kering memiliki efek untuk menghambat pertumbuhan Yoshida sarcoma dengan konsentrasi $5-10 \mu \mathrm{g} / \mathrm{ml}$. Norikura et al (2008) menemukan bahwa ekstrak metanol Blumea balsamifera memiliki aktivitas penghambatan perkembangan sel hepatoseluler karsinoma pada tikus dan mencit. Ekstrak metanol Blumea balsamifera dapat menginduksi cycle arrest pada fase G1 dengan cara menurunkan ekspresi cyclin-E, fosfolirasiprotein retinoblastoma ( $\mathrm{Rb})$, dan ligan penginduksi proliferasi yang dapat menstimulasi perkembangan sel tumor.

\section{Hepatoprotektif}

Kandungan flavonoid berupa blumetin pada Blumea balsamifera dilaporkan memiliki efek hepatoptotektor Blumetin dapat melindungi kerusakan sel hepatosit dari paparan parasetamol dan prednison (Xu at al, 1994). Flavonoid lain yang ada dalam daun sembung juga dilaporkan dapat melindungi kerusakan hapatosit yang terpapar $\mathrm{CCl} 4$ atau $\mathrm{FeSO}_{4}+$ cysteine Flavonoid dengan konsentrasi 10-100 $\mu \mathrm{mol} / \mathrm{L}$ dapat menghambat produksi malonaldehyde, penurunan GSH, danGPT(Pu at al, 2000). Kandungan Blumea flavone meurupakan yang paling kuat efek hepatoprotektornya (Xu at al, 1994).

\section{Antitirosin}

Saewan et al (2011) menemukan bahwa kandungan aktif dihydroquercetin-4'-methylether, dihydroquercetin-7,4'-dimethylether, quercetin, rhamnetin dan tamarixetin yang ada pada Blumea balsamifera memiliki aktivitas inhibisi yang lebih kuat dibandingkan dengan arbutin. Namun, kandungan daun sembung 5,7,3',5'-tetrahydroxyflavanone, blumetin, 
luteolin dan luteolin-7-methyl ether memiliki aktivitas antitirosin yang lebih lemah. Safiudin et al (2012) menjelaskan bahwa sequiterpene, beta-caryophyllene 8R,9R-oxide dari ekstrak metanol Blumea blasamifera dapat menghambat protein tyrosine phosphatase 1B (PTP1B).

\section{Antidiabetik}

Pada kasus diabetes, yang akan terjadi hiperglikemia persisten, glukosa darah yang berlebih akan bereaksi dengan hemoglobin dengan proses non-enzimatik menjadi hemoglobin glokosilat. Roy et al (2013) melaporkan bahwa ekstrak Blumea balsamifera secara signifikan dapat menurunkan peningkatan hemoglobin glikosilat pada tikus yang diinduksi streptozotocin. Lee et al (2012) melaporkan ekstrak Blumea balsamifera memiliki apigenin yang dapat menghambat enzim aldose reduktase pada tikus sehingga dapat mencegah komplikasi pada penyakit diabetes.

\section{Antiobesitas dan antiaterogenik}

Kubota et al (2009) melaporkan bahwa ekstrak Blumea balsamifera dapat menghambat akumulai lipid dan aktivitas glycerol-3-phosphate dehydrogenase (GPDH), yang penting untuk penurunan ekspresi dari faktor transkripsi adipogenik, seperti peroxisome proligerator-activated receptor $\gamma$, CCAAT element binding protein, dan leptin di adiposit 3T3-L1.

\section{Penyembuhan Luka}

Wang et al (2013) menemukan bahwa penggunaan minyak Blumea balsamifera pada kulit yang intak dan luka di tikus tidak memiliki toksisitas akut. Tikus yang diberi minyak sembung dengan dosis $2000 \mathrm{mg} / \mathrm{kg}$ selama 24 jam tidak ditemukan reaksi alergi dan toksisitas akut. Luka pada tikus ditemukan lebih bagus penyembuhannya dibandingkan dengan tikus yang tidak diberi minyak sembung.

\section{Antioksidan}

Ekstrak etanol Blumea balsamifera memiliki aktivitas penghambatan xanthine oxidase yang kuat dengan nilai $\mathrm{IC}_{50}$ value of $6.0 \mu \mathrm{g} / \mathrm{ml}$. Kandungan aktifnya berupa $(2 R, 3 S)-(-)-4^{\prime}-$ $O$-methyldihydroquercetin, quercetin, dan quercetin-3,3',4 memiliki aktivitas inhibisi yang lebih dari pada ekstrak etanol kasar dengan nilai $\mathrm{IC}_{50}$ values sekitar 0.23 sampai 1.91 mmol/l (Nguyen et al, 2004). Ekstrak metanol sembung menunjukkan aktivitas scavenging radikal 1,1-diphenyl-2-picrylhydrazyl (DPPH) dengan IC50 value dari $72 \mathrm{~g} / \mathrm{mL}$. Aktivitassuperoxide anion scavenging lebih $200 \mathrm{~g} / \mathrm{mL}$ (Syur et al, 2005). Roy et al (2013) melaporkan bahwa ekstrak daun sembung dapat meningkatkan enzim antioksidan glutation (GSH) dan katalase (CAT) pada tikus yang diinduksi streptozotocin, di mana steptozotocin dapat menginduksi hiperglikemia yang akan membuat radikal bebas yang menyebabkan kerusakan DNA, degenerasi protein, lipid peroksidase, dan bisa merusak berbagai macam organ.

\section{Aktivitas Antiperdarahan}

Kandungan blumetin dengan konsentrasi $1.26 \mu \mathrm{mol} / 1$ memiliki aktivitas agregasi platelet yang baik di tikus dan manusia yang disebabkan oleh asam arakidonat, 5-hydotypamice, dan epinefrin. Namun, konsentrasi 0.315 and $2.52 \mu \mathrm{mol} / \mathrm{l}$ justru berefek antiagregasi platelet (Xu et al, 1994).Yan et al (2015) menjelaskan ekstrak sembung juga dapat mempercepat pembekuan darah. 


\title{
Antiartritis
}

Fraksi etil asetal dari Blumea balsamifera dilaporkan dapat memiliki efek antiartritis dan antioksidan. Etil asetat sembung dosis tinggi dapat menurunkan pembengkakan pada sendi dan menurunkan index artiritis serta menurunkan hiperplasia synovial (Xia et al, 2014)

\section{Antiinflamasi}

Yan et al (2015) melaporkan bahwa ekstrak air dosis tinggi (92 $\mathrm{mg} / \mathrm{kg}$ ) dapat mengurangi edema sampai $6,4 \%$. Daun sembung juga dapat mengurangi PEG-2 dan transudasi protein. Xia melaporkan sembung dapat menurunkan sitokin inflamasi seperti IL-1, IL-6, TNF- $\alpha$ (Xia et al, 2014)

\section{Antibakteri}

Penelitian tentang efek antibakteri dari Blumea balsamifera masih kontroversial. Sakee et al (2011) bahwa meneliti tentang antibakteri minyak atisiri dan beberapa variasi ekstrak Blumeabalsamifera dan menyimpulkan bahwa efek antibakteri yang paling kuat berupa minyak atsiri. Minimum inhibitory concentration (MIC) minyak atsiri untuk bakteri Bacillus cereusadalah $150 \mathrm{mg} / \mathrm{ml}$, sedangkan MIC untuk bakteri Staphylococcus aureus adalah $1,2 \mathrm{mg} / \mathrm{ml}$. Sedangkan Ongsakul et al menyimpulkan bahwa ekstrak etanol dan ekstrak air Blumea balsamifera tidak memiliki efek antibacterial yang signifikan untuk melawan taphylococcus aureus and Escherichia coli. Sedangkan Katno et al (2009) melaporkan bahwa ekstrak etanol daun sembung konsentrasi 40\%, 60\%, 80\% dan 100\% dapat menghambat pertumbuhan bakteri Escherichia coli dan Staphylococcus aureus dengan zona inhibisi 14-23 mm dan 17-21 mm.

\section{Antiplasmodial}

Ekstrak metanol dari batang dan akar Blumea balsamifera dilaporkan memiliki efekantiplasmodial. Ekstrak batang dapat melawan Plasmodium falciparumdengan nilai IC50 $26.25 \pm 2.47 \mu \mathrm{g} / \mathrm{mL}$, sedangkan nilai IC50 efek antiplasmodial ekstrak akar adalah $7.75 \pm 0.35 \mu \mathrm{g} / \mathrm{mL}$ (Rain et al, 2007)

\begin{abstract}
Aktivitas Lain
Injeksi ekstrak Blumea balsamifera memiliki efek terhadap penurunan tekanan darah, pelebaran pembuluh darah, dan mengambat saraf simpatis yang merangsang tekanan tinggi dan imsomnia. Infusi sembung juga d memiliki efek diuresis (Xu et al, 1994).
\end{abstract}

\section{Potensi Penelitian}

Penelitian lebih lanjut tentang efek antibakteri Blumea balsamifera masih diperlukan dikarenakan terdapat hasil yang bertentangan dari penelitian terdahulu tentang ada tidaknya efek antibakterinya.

Penelitian tentang efek sembung terhadap diare, asma, wasir masih diperlukan karena sedikit jurnal ilmiah yang menjelaskan tentang efek atau mekanisme sembung mengatasi penyakit tersebut

\section{Daftar Pustaka}

Aguilar NO (1999). Blumea balsamifera (L.) DC.[Internet]. Dalam L.P.A. Oyen dan Nguyen Xuan Dung (Editors). PROSEA (Plant Resources of South-East Asia) Foundation, Bogor, Indonesia. http://proseanet.org/prosea/e-prosea_detail. php?frt=\&id=653. Diakses 20-Jan-201.6 
Ali DMS, Wong KC, Lim PK (2005). Flavonoids from Blumea balsamifera. Fitoterapia. $76: 128-30$.

Alonzo DS (1999). Blumea DC.[Internet]. Dalam Padua, L.S., Bunyapraphatsara, N. dan Lemmens, R.H.M.J. (Editors). PROSEA (Plant Resources of South-East Asia) Foundation, Bogor, Indonesia. http://proseanet.org/prosea/eprosea_detail.php?frt=\&id=176. Diakses: 20-Jan-2016

Badan Pengawas Obat dan Makanan Republik Indonesia (2008). Taksonomi koleksi tanaman obat kebun tanaman obat Citeureup. Jakarta: Direktorat Obat Asli Indonesia BPOM RI, pp: 15.

Balangcod TD, Vallejo VL, Patacsil M, Apostol O, Laruan LMVA, Manuel J, et al (2012). Phytochemical screening and Antibacterial activity of selected medicinal plants of Bayabas, Sablan, Benguet Province, Cordillera Administrative Region, Luzon, Philippines. Indian Journal of Traditional Knowledge. 11(4): 580-585

Bhuiyan NI, Chowdhury JU, Begum, J (2009). Chemical components in volatile oil from Blumea balsamifera(L.) DC. Bangladesh J. Botany, 38: 107-109.

Dalimartha S (2005). Tanaman obat di lingkungan sekitar. Jakarta: Puspa Swara, p: 45

De Guzman (2014). Country status report on medical and aromatic plants in the Philippiness. Dalam Paroda R, Dasgupta S, Mal B, Ghosh SP, Pareek SK. Expert Consultation on Promotion of Medicinal and Aromatic Plants in the Asia-Pacific Region: Proceedings, Bangkok, Thailand; 2-3 December, 2013, pp: 201-216

Fazilutan N, Zhari I, Nornisah M (2003). Antioxidant activity of extracts from the leaves of Blumea balsamifera DC and their major flavonoids with the $\alpha$-carotene-linoleic acid model system. Malaysian Journal of Pharmaceutical Sciences, 1: 51-64.

Fujimoto Y, Soemartono A, Sumatra M (1988). Sesquiterpene lactones from Blumea balsamifera. Phytochemistry, 27: 1109-1111.

Hariana (2014). Tumbuhan obat dan khasiatnya 3. Jakarta: Penebar Swadaya, pp:53-64K

Hasegawa H, Yamada Y, Komiyama K, Hayashi M., Ishibashi M, Yoshida T, Sakai T, et al (2006). Dihydroflavonol BB-1, an extract of natural plant Blumea balsamifera, abrogates TRAIL resistance in leukemia cells. Blood, 107: 679-688.

Huang YL, Zhao ZG, Wen YX (2006). Determination of total flavonoid in different sections of Blumea balsamifera. Guihaia, 26: 453-455.

Isnawati A, Raini M, Alegantina S (2006). Standarisasi Simplisia dan Ekstrak Etanol Daun Sembung (Blumea balsamifera (L)) dari Tiga Tempat Tumbuh. Media Litbang Kesehatan XVI (2): 1-6

Jiang Z, Xhou Y, Ge W, Yuan K (2014). Phytochemical compositions of volatile oil from Blumea balsamiferaand their biological activities.PharmacognMag. 10(39): 346352.

Katno, Haryanti S, Triyono A (2009). Uji daya hambat ekstrak etanol daun sembung (Blumea balsamifera (L.) DC) terhadap pertumbuhan mikroba E. coli, S. aereus dan C. albicans. Jurnal Tumbuhan Obat Indonesia. 2(1): 33-36

Kihno J, Arini DID, Halawane J, Nurani L, Halidah, Kafiar Y, Karundeg MC (2011.) Tumbuhan obat tradisional di Sulawesi Utara Jilid II. Manado: Balai Penelitian Kehutanan Manado, pp: 31-33

Kubota H, Kojima-Yuasa A, Morii R, Huang X, Norikura T, Rho SN, Matsui-Yuasa (2009). Anti-obesity effect of Blumea balsamiferaextract in 3T3-L1 preadipocytes and adipocytes. Am. J. Chin. Med, 37: 843-854.

Lee DG, Mok SY, Choi C, Cho EJ, Kim HY, Lee S (2012). Analysis of apigenin in Blumea balsamiferaLinn DC. and its inhibitory activity against aldose reductase in rat lens. Journal of Agricultural Chemistry and Environment, 1(1): 28-33 
Liang HL, Cao PX, Qiu JY, Li X, Cai L, Liang GY (2011). Study on the chemical constituents of Blumea balsamiferaDC. Lishizhen Med. Mater. Med. Res,22: 308309.

Nguyen MT, Awale S, Tezuka Y, Tran QL, Watanabe H, Kadota S (2004) Xanthine oxidase inhibitory activity of Vietnamese medicinal plants. Biol. Pharm. Bull. 27: 1414-1421

Noor RA, Khozirah S, Mohd RM, Ong BK, Rohaya C, Rosilawati M, Hamdino I, et al (2007). Antiplasmodial properties of some Malaysian medicinal plants. Trop. Biomed, 24: 29-35.

Norikura T, Kojima-Yuasa A, Shimizu M, Huang X, Xu, S, Kametani S, Rho S, et al (2008). Mechanism of growth inhibitory effect of Blumea balsamifera extract in hepatocellular carcinoma. Biosci. Biotechnol. Biochem,72: 1183-1189.

Pang Y, Wang D, Fan Z, Chen X, Yu F, Hu X, Wang K, et al (2014). Blumea balsamifera - a phytochemical and pharmacological review. Molecules, 19: 9453-9477.

$\mathrm{Pu} \mathrm{HL}$, Zhao, JH, Xu SB, Hu Q (2000). Protective actions of Blumea flavanones on primary cultured hepatocytes against lipid peroxidation. Chin. Trad. Herb. Drug.,31: 1113-1115.

Rain AN, Khozirah S, Ridzuan MARM, Ong BK, Rohaya C, Rosilawati M, Hamdino L, et al (2007). Antiplasmodial properties of some Malaysian medical plants. Tropical Biomedicine, 24 (1): 29-35.

Roy K, Saha S, Biswas S, Ahmed W, Mariappan G (2013). In vivo assessment of antidiabetic and antioxidant activities of Blumea balsamifera in streptozotocindiabetic rats. Research Jouenal of Medical Plant7 (1) : 48-57

Saewan N, Koysomboon S, Chantrapromma K (2011). Anti-tyrosinase and anti-cancer activities of flavonoids from Blumea balsamiferaDC. J. Med. Plants. Res., 5: 10181025.

Safiudin A, Tanaka K, Kadota S, Tezuka Y (2012) Chemical constituents of Blumea balsamifera of Indonesia and their protein tyrosine phosphatase $1 \mathrm{~B}$ inhibitory activity. Nat Prod Commun. 7(7): 815-818.

Sakee U, Maneerat S, Cushnie T, De-eknamkul W. Antimicrobial activity of Blumea balsamifera (Lin.) DC. extracts and essential oil. Natural Product Research. 25(19): 1849-1856

Shyur L, Tsung J, Chen J, Chiu C, Lo C (2005). Antioxidant properties of extracts from medicinal plants popularly used in Taiwan. Int. J. Appl. Sci. Eng., 3: 195-202.

Sudiarto A, Putera TD (2008). Buku pintar tanaman obat. Jakarta: Agromedia Pustaka, pp: 222

Wang D, Fu WJ, Pang YX, Wang H, Hu X, Nie H (2013). The study of skin allergy and acute toxicity of Blumea balsamiferaoil. Chin. J. Trop. Crop., 34: 2499-2502.

Xia Y, Zuo J, Li X, Chen JW (2014). [Anti-arthritic and anti-oxidative effect of ethyl acetate fraction of Blumea balsamlfera residues in rat adjuvant-induced arthritis]. Zhongguo Zhong Yao Za Zhi, 39(19): 3819-23.

Xia Y, Li X, Chen JW (2015). Anti-inflammatory, analgesic and hemostasis activities of different extracting fractions of Blumea balsamifera Residue. Natural Product Research and Development, 27(6) 1086-1091

Xu SY, Bian RL, Chen X (1994) Methodology of pharmacological experiments, 2nd ed. Beijing, China: People's Medical Publishing House

Xu SB, Hu Y, Lin YC, Yang ZB (1994). Study on protection of blumeatin against experimental liver injury and aggregation of platelet. Suppl. J. Sun Yatsen Univer.1994: 48-53. 